\title{
Protein Intake, Distribution and Food Sources in Adults of Advanced Age: Life and Living in Advanced Age: A Cohort Study in New Zealand $\left(\right.$ LiLACS NZ) ${ }^{\dagger}$
}

\author{
Anishka Ram 1, Ngaire Kerse 2, Simon Moyes 2, Anna Rolleston ${ }^{2}$ and Carol Wham 1,* \\ 1 School of Sport, Exercise and Nutrition, Massey University, Auckland 0632, New Zealand; \\ aram2@massey.ac.nz \\ 2 School of Population Health, University of Auckland, Tamaki Campus, Auckland 1142, New Zealand; \\ n.kerse@auckland.ac.nz (N.K.); s.moyes@auckland.ac.nz (S.M.); anna@thecentreforhealth.co.nz (A.R.) \\ * Correspondence: c.a.wham@massey.ac.nz; Tel.: +64-9-213-6644 \\ + Presented at the 2019 Annual Meeting of the Nutrition Society of New Zealand, Napier, New Zealand, \\ 28-29 November 2019.
}

Published: 13 December 2019

Protein intake and its food sources is important to prevent age related loss of muscle mass and strength. An even protein intake distribution throughout the day has been suggested as necessary to stimulate muscle protein synthesis. This study examined the prevalence and determinants of inadequate protein intake, primary food sources and mealtime distribution of protein in Māori and non-Māori of advanced age.

Dietary intake was assessed in 214 Māori and 360 non-Māori octogenarians with a repeat 24hour multiple pass recall. Adequate protein intake was determined using estimated average requirement (EAR) cut-off points of $\leq 0.75 \mathrm{~g} / \mathrm{kg}$ for women and $\leq 0.86 \mathrm{~g} / \mathrm{kg}$ for men. Contribution (\%) of the primary food groups to protein intake were assessed. Protein intake distribution was determined for the three main meals. A logistic regression model was built to predict meeting the EAR for protein intake per adjusted body weight per day.

Total median (IQR) protein intake for women was $0.87(0.68-1.12) \mathrm{g} / \mathrm{kg}$ and for men was 0.97 $(0.78-1.21) \mathrm{g} / \mathrm{kg}$. The EAR for protein was not met by a third of both women $(30.9 \%)$ and men $(33.3 \%)$. Main food group contributors to protein were beef/veal, fish/seafood, milk, bread and differed by gender and ethnicity. For women and men respectively protein distribution $(\mathrm{g} / \mathrm{meal})$ was lowest at breakfast (10.1 g and $13.0 \mathrm{~g}$ ), followed by lunch (14.5 and 17.8 g) and dinner (23.3 and 34.2). Being a woman and having depressive symptoms were associated with consuming less total protein. Controlling for all other variables the odds of meeting the EAR for protein was higher in participants who had their own teeth or partial dentures $(p=0.036)$.

Among advanced age Māori and non-Māori these findings highlight the prevalence of low protein intake, uneven mealtime protein distribution and importance of dentition for adequate protein intake.

(C) 2019 by the authors. Licensee MDPI, Basel, Switzerland. This article is an open access article distributed under the terms and conditions of the Creative Commons Attribution (CC BY) license (http://creativecommons.org/licenses/by/4.0/). 